\title{
Urinary IgG antibody against mixed heat-killed coliform antigen and lipopolysaccharide core antigen
}

\author{
A P Gibb, D M Edmond
}

\begin{abstract}
Aims: To determine whether antibody to lipopolysaccharide-core(LPS-core) antigen is an important component of the antibody, detected by mixed heat-killed coliform antigen, in urine from patients with suspected urinary tract infection.

Methods: LPS-core antigen and mixed heat-killed coliform antigen were used in an enzyme linked immunosorbent assay (ELISA) to measure IgG antibody in midstream urine samples. Seventy two samples from students attending their general practitioner with symptoms suggestive of urinary tract infection, six samples from which a Gram positive organism was isolated, and 16 asymptomatic controls were tested. Plates coated with LPS-core antigen were also used to absorb out the antibody detected by the mixed heat-killed coliform antigen.
\end{abstract}

Results: Antibody to either antigen was associated with a positive culture, but neither was a useful predictor of a positive culture. There was a significant correlation between the results of the two assays $(r=0.7633 ; p<0.001)$, and absorption with LPS-core antigen did reduce the level of antibody to the mixed heatkilled coliform antigen. Antibody to both preparations was found in patients with Gram positive urinary tract infection. Conclusions: Antibody to LPS-core antigen forms a substantial part of the antibody detected by mixed heat-killed coliform ELISA. The antibodies detected by these assays are probably the result of non-specific leakage of antibody into the urine, rather than a specific immune response.

Studies of antibacterial antibody in urine during urinary tract infection have mainly focused on specific responses to organisms isolated from individual patients, ${ }^{1-4}$ and have been mainly directed towards distinguishing between pyelonephritis and cystitis. ${ }^{13}$ An alternative approach has been to look for urinary antibody to a wide range of likely pathogens, and to use this as a tool for the primary diagnosis of urinary tract infection. ${ }^{56} \mathrm{~A}$ test based on this concept (Uristat, Shield Diagnostics, Dundee) has been marketed in the United Kingdom. This approach to the diagnosis of urinary tract infection has the theoretical advantage that urinary antibody would not be prone to the problems of contamination and overgrowth associated with quantitative bacterial culture, and would be more stable than pus cells. It has the disadvantage, however, that there is a dearth of basic information about the clinical importance of this kind of antibody in urinary tract infection.

The aim of this study was to investigate the nature and clinical relevance of the antibody detected by the mixed heat-killed coliform ELISA (MHCE) described by Mackenzie and Young. ${ }^{5}$ It was decided to concentrate on IgG because this was the main antibody class that had been detected in that assay. Secretory IgA was considered but rejected on the grounds that it has not been found consistently in urine in urinary tract infection. ${ }^{45}$ The core region of LPS (LPS-core) was thought likely to be an important antigen in the assay for two reasons. First, LPS-core is a heat stable antigen which is present in all Gram negative bacteria. It would thus be present in the MHCE antigen preparation used. Second, LPS-core antibody is found frequently in serum from the normal human populations, ${ }^{7}$ confirming that this antibody is part of the human immunological repertoire. A urinary antibody response to urinary tract infection might therefore be expected to include antibody to LPS-core antigen, and this antibody would be detected by the MHCE assay.

\section{Methods}

Seventy two urine specimens were collected from students with suspected urinary tract infection attending general practitioners at the University of Edinburgh Students' Health Centre. None of these patients was thought to have pyelonephritis. One patient who was known to be taking antibiotics was excluded. Most were subsequently treated with antibiotics, and none returned because of persisting symptoms. These specimens were collected under the supervision of an experienced nurse and were then brought directly to the diagnostic laboratory by the patient. Urine specimens from patients with Gram positive urinary infection were selected after culture from among all specimens sent to the diagnostic laboratory by general practitioners. Control samples were obtained from 16 asymptomatic students.

Microscopy was performed using an inverted microscope. Ten pus cells per field 
(equivalent to 20 per $\mathrm{mm}^{3}$ ) was scored positive. Cultures (standard loop) containing $>10^{5}$ colony forming units (cfu) $\mathrm{ml}$ of a single bacterial species were considered positive, and specimens containing $10^{4}-10^{5} \mathrm{cfu} / \mathrm{ml}$ were reported as doubtful.

Urine samples were centrifuged at $4000 \times g$ for 10 minutes and the supernatant stored in 1 $\mathrm{ml}$ volumes at $-20^{\circ} \mathrm{C}$ before analysis for antibody.

\section{ELISA PLATES}

For MHCE assay, plates were coated with a mixture of six coliform organisms (four $E$ coli, one Klebsiella, one Proteus) isolated from urine specimens. The coating suspension was prepared as follows: each organism was grown overnight in nutrient broth at $37^{\circ} \mathrm{C}$, washed, and resuspended in phosphate buffered saline (PBS). The concentration was adjusted so that a 1 in 10 dilution had an extinction level of 0.25 at $540 \mathrm{~nm}$. The suspension was then heated to $100^{\circ} \mathrm{C}$ for 30 minutes. The six preparations were mixed together in equal parts and the mixture diluted 1 in 10 with $0.05 \mathrm{M}$ carbonatebicarbonate coating buffer ( $\mathrm{pH} 9 \cdot 6$ ). Nunclon polysorb strips were coated with $100 \mu \mathrm{l}$ of antigen preparation in each well and incubated at room temperature overnight. Each well was then washed four times with wash buffer (PBS with $0.05 \%$ sodium azide and $0.1 \%$ Tween20). Plates coated with LPS-core were donated by Dr GR Barclay, Blood Transfusion Service, Edinburgh. ${ }^{7}$ These were prepared using LPS purified by phenol/chloroform/petroleum extraction from four rough mutant bacteria, Salmonella typhimurium Rc878, Escherichia coli $\mathrm{K} 12$, Klebsiella aerogenes $\mathrm{M10B}$, and Pseudomonas aeruginosa PAC605. Each was made up to a concentration of $0.2 \mathrm{mM}$ in water and complexed with $0.4 \mathrm{mM}$ polymixin $B$. Equal volumes of each antigen were mixed to give a final LPS-core concentration of $0.1 \mathrm{mM}$ and $100 \mu \mathrm{l}$ per well was dispensed into Nuclon maxisorb plates, incubated overnight at room temperature, and washed as above. PBS containing $5 \%$ bovine serum albumin $(100 \mu \mathrm{l})$ was then added to each well, incubated overnight at room temperature, and washed as above. Plates were stored at $-20^{\circ} \mathrm{C}$.

\section{URINE ANTIBODY ASSAYS}

Urine samples $(100 \mu \mathrm{l})$ were added in duplicate to microplate wells, incubated at $37^{\circ} \mathrm{C}$ for one hour, and washed four times. Alkaline phosphatase labelled anti-human IgG (ICN Immunologicals) was diluted 1 in 500 in ELISA diluent (PBS containing 0.05\% Tween-20, $0.5 \%$ bovine serum albumin, $4 \%$ $(w / v)$ polyethylene glycol 6000 , and $0.05 \%$ sodium azide), and $100 \mu \mathrm{l}$ added to each well, incubated for one hour at $37^{\circ} \mathrm{C}$, and washed four times. P-nitrophenyl phosphate $(100 \mu \mathrm{l}$ of a $1 \mathrm{mg} / \mathrm{ml}$ solution: Sigma) in $0.05 \mathrm{M}$ sodium carbonate, $1 \mathrm{mM}$ magnesium chloride, $\mathrm{pH} 9 \cdot 8$, was added and the colour measured at $405 \mathrm{~nm}$ after 30 minutes at room temperature. Each assay included duplicate blank wells with no urine added, and duplicate reference wells containing standard human IgG (IgG from pooled blood donor sera, donated by Dr GR Barclay, diluted to $50 \mu \mathrm{g} / \mathrm{ml}$ in ELISA diluent and stored at $-20^{\circ} \mathrm{C}$ ). Wells without antigen but washed and post-coated as above were also used as negative controls.

\section{ABSORPTION ASSAY}

Samples $(100 \mu \mathrm{l})$ of antibody positive urine were added in duplicate to wells coated with LPS-core antigen and incubated at $37^{\circ} \mathrm{C}$ for one hour. The samples were then transferred to Wells freshly coated with LPS-core antigen. Incubation and transfer were repated twice so that each sample had been incubated for a total of three hours in three separate wells. Antibody was then measured using MHCE coated plates. Antibody results were compared with those for unabsorbed urine and urine that had been absorbed in control wells (wells containing no LPS-core antigen but washed and post-coated with albumin in the same way as LPS-core coated wells).

\section{STATISTICAL ANALYSES}

Data were analysed using the Statistical Package for Social Sciences (SPSS-PC) (Information Analysis Systems).

\section{Results}

For all but one of the asymptomatic controls, antibody results $\left(\mathrm{OD}_{405}\right)$ were $<0.1$ with both MHCE and LPS-core antigens. One male asymptomatic control did have consistently high titres of urinary antibody to both antigens $\left(\mathrm{OD}_{405}>1 \cdot 0\right)$. He did not have covert urinary tract infection, haematuria, proteinuria, hypertension, or any other evidence of renal or other disease.

Of the 72 specimens from symptomatic patients, 19 were culture positive $\left(>10^{5} \mathrm{cfu} /\right.$ $\mathrm{ml}$, all with coliforms), and the remaining 53 were culture negative $\left(<10^{4} \mathrm{cfu} / \mathrm{ml}\right)$. Pus cells were seen in 17 of the 19 culture positive specimens, and in one of the 53 culture negative specimens.

IgG antibody was detected by both LPScore ELISA and MHCE in the urine samples of most of the symptomatic patients (fig 1).

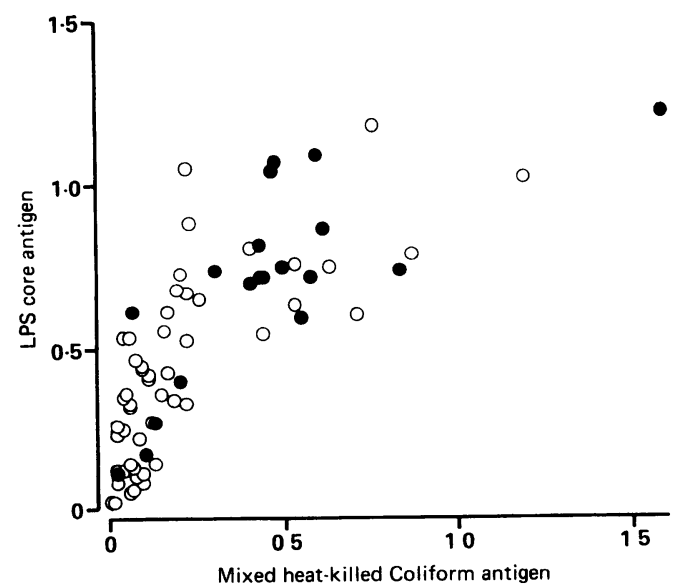

Figure 1 Correlation of IgG antibody (OD) with mixed, heat-killed coliform and LPS-core antigens in 72 urine samples from symptomatic patients $=$ culture positive; $\mathrm{O}=$ culture negative. 
Table 1 IgG antibody (OD) to individual and mixed LPS-core antigens in eight positive urine samples

\begin{tabular}{llllll}
\hline \multicolumn{5}{l}{ Antibody titres $\left(O D_{\text {tos }}\right)$ detected by LPS-core from } \\
\cline { 3 - 6 } Sample No & Mixed & Klebsiella aerogenes & Pseudomonas aeruginosa & E coli & Salmonella typhimurium \\
\hline 1 & 1.346 & 0.393 & 0.435 & 0.440 & 0.535 \\
2 & 1.310 & 1.087 & 1.135 & 1.077 & 1.012 \\
3 & 0.293 & 0.154 & 0.135 & 0.140 & 0.205 \\
4 & 0.992 & 0.758 & 0.719 & 0.587 & 0.722 \\
5 & 0.969 & 0.340 & 0.452 & 0.400 & 0.528 \\
6 & 0.888 & 0.507 & 0.480 & 0.513 & 0.473 \\
7 & 0.995 & 0.463 & 0.478 & 0.514 & 0.672 \\
8 & 1.302 & 0.358 & 0.256 & 0.300 & 0.676 \\
\hline
\end{tabular}

Antibody positive specimens from symptomatic patients had detectable titres of antibody against all of the individual bacteria which went to make up the MHCE antigen, as found by McKenzie and Young. ${ }^{5}$ Similarly, the individual LPS-core antigens permitted the detection of antibody (table 1 ).

For the symptomatic patients there was a significant correlation between antibody to LPS-core antigen and antibody to MHCE antigen $(r=0.7633, p<0.001)$. Within this group there was also a significant association between antibody titre and positive culture for both LPS-core antigen $(t=3.65 ; \mathrm{p}<0.001)$ and MHCE antigen $(t=3.55 ; \mathrm{p}<0.001)$. The predictive value of the antibody tests for positive culture was, however, low. For LPScore antigen, an $\mathrm{OD}$ value of $>0.6 \mathrm{OD}$ predicted positive culture with a sensitivity of $15 / 19$ $(79 \%)$ and a specificity of $15 / 30(50 \%)$. For the MHCE antigen an OD of $>0.4$ predicted positive culture with a sensitivity of 13/19 $(68 \%)$ and a specificity of $13 / 21(62 \%)$.

The correlation between the two assays suggested that they were measuring the same antibody. This was supported by the demonstration that the antibody detected by the MHCE antigen was reduced following absorption by LPS-core antigen in coated wells (fig 2).

Because LPS-core antigen is present only in Gram negative bacteria it might be predicted that this antibody would not be found in urinary tract infection caused by Gram positive organisms. Antibody to both antigens, however, was found in all six urine samples from symptomatic patients from which $>10^{5}$ Gram positive organisms were grown in pure culture (table 2 ).

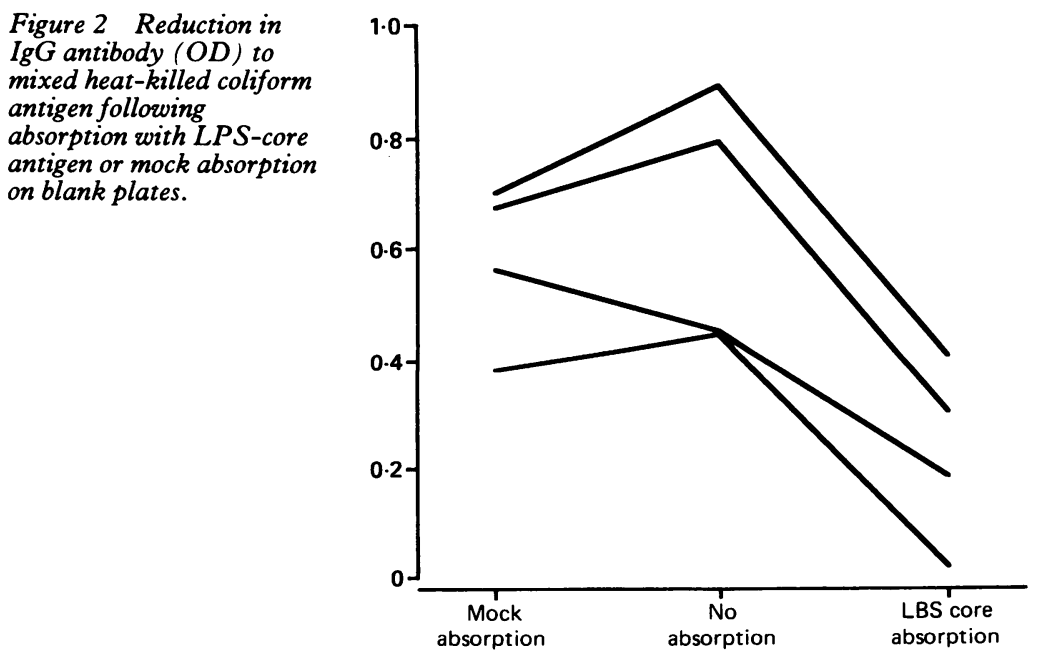

\section{Discussion}

The results presented here show that the presence of urinary IgG antibody detected in the MHCE assay is correlated with the presence of anti-LPS-core IgG. The assays could be measuring two quite separate antibodies which happen to occur together, or they could be measuring the same antibody. The demonstration that the coliform antibody can be reduced by absorption with LPS-core antigen suggests that antibody to LPS-core antigen makes up a sizeable proportion of the antibody detected by the MHCE antigen. This in part reflects the fact that other antigens in the MHCE assay will have been denatured by heat (in the case of proteins) or will be highly strain specific (in the case of 0 antigens). It may also indicate that antibody to LPS-core is an important part of the host immune response in urinary tract infection, as it is thought to be in septic shock. ${ }^{8}$

The simplest explanation for the presence of IgG core and coliform antibody in urine during urinary tract infection would be that inflammation and leakage of plasma proteins results in the presence in urine of unselected IgG antibodies from serum, as is thought to occur in pyelonephritis. ${ }^{4}$ This would explain why the antibody is present early in the course of infection, when patients are presenting to their GP with symptoms. A specific immune response to infecting organisms would not be expected to result in an antibody response at this stage. It would also explain why the antibody is not a specific response to the infecting organisms, as is seen in the Gram positive infections. Such antibody would probably also be found in gonococcal or chlamydial urethritis, conditions which should be differentiated from simple urinary tract infection and managed differently.

Urinary IgG antibody to both antigen preparations was found in many of the symptomatic but culture negative patients as well as in those with positive cultures. Similar results were obtained by McKenzie and Young. ${ }^{5}$ Antibacterial substances in urine could account for some false negative cultures, but we have found such substances in less than $1 \%$ of urine samples from the students' health centre in previous studies (unpublished). Undiagnosed urethritis, or urinary tract infection with $<10^{4}$ $\mathrm{cfu} / \mathrm{ml}$, might be present in some cases, but the absence of large numbers of pus cells in all but one of the culture negative specimens militates against this. ${ }^{9}$ There is no satisfactory explanation for the presence of acute urinary symp- 
Table 2 IgG antibody (OD) to mixed heat-killed coliform and LPS-core antigen in six urine samples with Gram positive infection

\begin{tabular}{llll}
\hline \multirow{2}{*}{$\begin{array}{l}\text { Sample } \\
\text { No }\end{array}$} & $\begin{array}{l}\text { Cultured Gram } \\
\text { positive organism }\end{array}$ & \multicolumn{2}{l}{ Antibody titre $\left(O D_{\text {405 }}\right)$ detected by } \\
\cline { 3 - 4 } & EHCE antigen & LPS-core antigen \\
\hline 1 & Enterococcus & 0.256 & 0.571 \\
2 & Enterococcus & 0.589 & 1.054 \\
3 & Staphylococcus saprophyticus & 0.265 & 0.584 \\
4 & Staphylococcus saprophyticus & $0 \cdot 100$ & $0 \cdot 227$ \\
5 & Staphylococcus saprophyticus & 0.688 & 1.235 \\
8 & Group G Streptococcus & 0.528 & 1.091 \\
\hline
\end{tabular}

toms in many patients, however, ${ }^{910}$ and it is therefore impossible to relate these findings to established underlying mechanisms. The presence of antibody does suggest that the symptoms have a physiological basis.

The purpose of measuring urinary antibody to a mixture of common urinary pathogens ${ }^{5}$ was that it would permit rapid detection of urinary tract infection and would be less sensitive to contamination or overgrowth than is conventional bacteriology. In our hands IgG coliform or core antibody did not predict positive culture in fresh, carefully taken specimens to any useful extent. Such antibody tests are therefore not likely to be useful in examining contaminated specimens or specimens which have been delayed, or where the patients have been on antibiotics. Other workers have found that measuring lipopolysaccharide antibodies in urine is not a useful way of screening urine samples before culture. ${ }^{6}$

It is clear that urinary antibodies can be measured in association with symptoms sug- gestive of urinary tract infection. It may be possible to define particular classes or specificities of urinary antibody which are of predictive value in the diagnosis of urinary tract infection. There is, however, much to be learned about the relation between urinary tract infection and urinary antibodies before such a test can be devised.

1 Ratner JL, Thomas VL, Sanford BA, Forland M. Bacteria specific antibody in the urine of patients with acute pyelonephritis and cystitis. J Infect Dis 1981;143:404-12.

2 Short KL, West CA, Brinson D, et al. Comparison of 0 antigen-specific urinary immunoglobulins to Escherichia coli in normal women and women prone to Escherichia coli in normal women and women pron

3 Sohl Ackerlund A, Ahlstedt S, Hanson LA, Jodal U. Antibody responses in urine and serum against Escherichia coli $O$ antigen in childhood urinary tract infections. Acta Pathol Microbiol Scandinavica (Sect C) 1979;87 29-36.

4 Svanborg Eden C, Kulhavy R, Marild S, Prince SJ, Mestecky J. Urinary immunoglobulins in healthy individuals and children with acute pyelonephritis. Scand J Immunol 1985;21:305-13.

5 McKenzie H, Young DN. Antibody to coliform antigens in urine samples from patients with symptoms of urinary urine samples from patients with symptoms

6 MacGowan AP, Marshall JP, Cowling P, Reeves DS. Measurement of urinary lipopolysaccharide antibodies by ELISA as a screen for urinary tract infection. J Clin Pathol ELISA as a scr

7 Scott BB, Barclay GR. IgG antibodies to Gram-negative endotoxin in human serum. I. Lipopolysaccharide (LPS) cross reactivity due to antibodies to LPS core. Serodia Immunother Infect Dis 1990;4:25-38.

8 Barclay GR, Scott BB, Wright IH, Rogers PN, Smith DGE Poxton IR. Changes in anti-endotoxin-IgG antibody and endotoxaemia in three cases of gram-negative septic shock. Circulatory Shock 1989;29:93-106.

9 Stamm WE, Wagner KF, Ansel R, et al. Causes of the acute urethral syndrome in women. $N$ Engl J Med 1980; 303:409-15.

10 Stamm WE, Counts GW, Running KR, Fihn S, Turck M Holmes KK. Diagnosis of coliform infection in acutely dysuric women. N Engl J Med 1982;307:463-71. 